\title{
The influence of temperature on algal biomass growth for biogas production
}

\author{
Monika Pawlita-Posmyk ${ }^{1, *}$, Małgorzata Wzorek $^{1}$, and Małgorzata Płaczek ${ }^{1}$ \\ ${ }^{1}$ Department of Process Engineering, Faculty of Mechanical Engineering, Opole University of Technology, Opole, Poland
}

\begin{abstract}
The use of algae is gaining popularity in recent years. Algae can form a suitable substrate for biogas production because they are low in cellulose and have low lignin content. The paper contains a summary with the list of the algae species applied for the biogas production process to this date, coupled with the description of the characteristic conditions in which the process is conducted. The key importance factors during the production of biogas include, among others, grade of algae species used, temperature of the process, mode in which the material is supplied into the tank, mixing method, use of co-substrate, etc. This paper reports the results of the study involving the effect of various temperature conditions on the characteristics of the growth rate of algal biomass. The research was performed for the Chlorella vulgaris BA-0167 strain in the temperature range corresponding to the mesophilic fermentation processes in anaerobic conditions.
\end{abstract}

\section{Introduction}

Global demand for energy from renewable sources is constantly growing. What shows a promise of development is the production of energy from the biomass of algae, which allow fulfilment of energysupply needs and limit $\mathrm{CO}_{2}$ emission at the same time. Moreover, microalgae grow at exceptional pace (100 times faster than land plants) and some strains of microalgae, including Chlorella vulgaris, can accumulate large amounts of lipids, which can be transformed into biodiesel [1]. The recent years have witnessed a significant increase in the use of algaederived biomass in various industry branches, e.g. in medicine, pharmacy, cosmetology, food industry and agriculture [2]. Algae are also used in the sewage treatment process $[3,4]$. Results of studies indicate that it is possible to use algae-derived biomass as a source of organic matter in production of biofuels, including biogas (Fig. 1) $[5,6]$.

Biogas can be produced from agricultural waste, solid municipal waste, sewage, waste from wood processing processes, industrial remains and animal waste. The composition of biogas depends on the applied substrate. Its main ingredients are $\mathrm{CH}_{4}(40-70 \%)$ and $\mathrm{CO}_{2}(15-60 \%)$, other chemical compounds $\left(\mathrm{H}_{2} \mathrm{O}, \mathrm{N}_{2}, \mathrm{O}_{2}\right.$, $\mathrm{H}_{2}, \mathrm{NH}_{3}, \mathrm{H}_{2} \mathrm{~S}$ ) occur in low amounts [7]. Among factors regarded as key in production of biogas using algae, there are for instance the types of used algae, process temperature, way of reactor feeding, mixing manner or the presence of a co-substrate.

Table 1 shows literature data [8-14] concerning the use of various algae species in production of biogas along with the description of conditions under which the process was conducted.

Dębowski et al. [5] point to factors which can considerably limit the effectiveness of methane fermentation and, in turn, contribute to decrease in or full inhibition of biogas production. Those factors include the presence of cellular wall, which is resistant to degradation under anaerobic conditions due to the presence of cellulose or hemicellulose compounds, presence of strains of microorganisms producing compounds toxic for anaerobic bacteria and an unfavourable $\mathrm{C}: \mathrm{N}$ relation in the biomass subjected to fermentation.

The aim of the study is to determine the effect of temperature on the effectiveness of production of biomass from microalgae Chlorella vulgaris BA-0167. Taking into consideration that Chlorella vulgaris is treated as a potential source of biomass for energy supply purposes, including biogas production, the possibility to cultivate algae within temperatures adequate for anaerobic mesophilic fermentation, i.e. $33^{\circ} \mathrm{C}-40^{\circ} \mathrm{C}$ was examined.

\section{General characteristic of microalgal biomass as a raw material for biogas production}

Algae form a source of valuable substances, i.e. proteins, lipids, hydrocarbons, vitamins and microelements. Water forms the principal component of the biomass, as it is $75-90 \%$ of the harvested mass before processing. The remaining ratio of the content is made by mineral salts and hydrocarbons $(30-50 \%)$ and lipids $(7-15 \%)$ of the dry mass $[3,15]$.

Algae biomass productivity in laboratory scale depends on many factors, e.g. on technical conditions under which algae grow, including design of photobioreactor, availability of food ingredients, light intensity, $\mathrm{CO}_{2}$ concentration and $\mathrm{pH}$ level.

\footnotetext{
* Corresponding author: mpawlita@wp.pl
} 


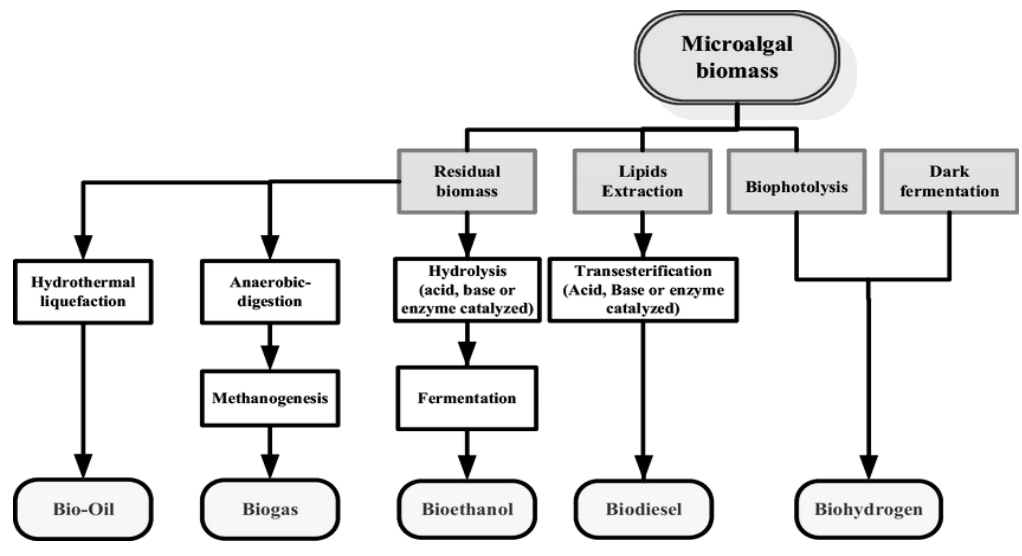

Fig. 1. Processes and products obtained from algae-derived biomass [6].

Mixing is another important aspect of algae cultivation as it guarantees maintenance of homogenous conditions in the entire culture, i.e. it protects against temperature gradient in the tank, guaranteeing, in turn, uniform access to nutrients and light $[3,16]$. The optimal temperature for algae growth should oscillate within 20 to $30^{\circ} \mathrm{C}[17-21]$ and according to the authors [22] it should remain within the range of 15 to $26^{\circ} \mathrm{C}$. The authors of the paper [22] indicate that the maximum algae growth occurs at $23{ }^{\circ} \mathrm{C}$ and the minimum one - at $7{ }^{\circ} \mathrm{C}$. Temperature below $16^{\circ} \mathrm{C}$ contributes to retardation of algae cell growth and temperature higher than $35^{\circ} \mathrm{C}$ is regarded as lethal point [21]. Therefore, in order to achieve the maximum algae productivity, it is recommended to hold a culture at the temperature corresponding to the optimum for a given species $[18,19$, 21]. Example of optimal temperature and favourable $\mathrm{pH}$ value for the growth of selected algae strains is presented in Table 2. The authors of study [28] stated that algae strains cultivated at temperatures $35^{\circ} \mathrm{C}$ and higher show a high level of photoinhibition and in this conditions the algae cells can start to decay. In turn, mechanical mixing may contribute to destruction of cells due to occurrence of shear forces $[18,19]$. The use of natural or artificial light is necessary to provide correct conditions for algae growth. Artificial lighting in the photobioreactor considerably increases the biomassproduction cost, but can also provide higher productivity of culture $[17,19]$.
Chisti [29] indicates that in order to obtain high algae growth, the following mineral ingredients are to be included in the nutrient medium: nitrogen $(\mathrm{N})$, phosphorus $(\mathrm{P})$, iron $(\mathrm{Fe})$ and silicon $(\mathrm{Si})$ in some cases. In turn, Voloshin et al. [30] state that for the efficient biomass increase of the desirable content, it should contain sufficient sources not only of carbon, but also of various necessary mineral elements: nitrogen and phosphorus in significant amounts, and magnesium, calcium, chlorine, silicon, manganese, iron in smaller amounts.

Algae cultures can be cultivated in various types of photobioreactors as apparatuses where it is possible to create proper conditions for cultivation and, at the same time, obtaining of high effectiveness of algae-derived biomass production [3].

Table 2. Example of optimal temperature conditions for algae cultivation.

\begin{tabular}{|c|c|c|c|}
\hline \multirow{2}{*}{ Algae species } & \multicolumn{2}{|c|}{ Optimal conditions } & \multirow{2}{*}{ Ref. } \\
\cline { 2 - 3 } & temperature & $\mathbf{p H}$ & \\
\hline $\begin{array}{c}\text { Chlorella thermophila } \\
\text { (HTA1-65) }\end{array}$ & $33^{\circ} \mathrm{C}$ & n.d. & {$[1]$} \\
\hline Chlorella vulgaris & $25-28^{\circ} \mathrm{C}$ & n.d. & \\
\hline Chlorella mirabilis & $10.1-20.5^{\circ} \mathrm{C}$ & n.d. & {$[23]$} \\
\hline Chlorella pyrenoidosa & $33^{\circ} \mathrm{C}$ & 9.0 & {$[24]$} \\
\hline Chlorella sp. & $37.5^{\circ} \mathrm{C}$ & 7.0 & {$[25]$} \\
\hline Chlorella marina & $37.5^{\circ} \mathrm{C}$ & 8.0 & \\
\hline Chlorella vulgaris & $27^{\circ} \mathrm{C}$ & n.d. & {$[26]$} \\
\hline Chlorella & $25-30^{\circ} \mathrm{C}$ & n.d. & {$[27]$} \\
\hline \multicolumn{3}{|c}{} \\
\hline
\end{tabular}

Table 1. Example conditions for biogas production process.

\begin{tabular}{|c|c|c|c|c|}
\hline Algae species & $\begin{array}{c}\text { Co- } \\
\text { substrates }\end{array}$ & Operating conditions & Biogas/methane production & Ref. \\
\hline $\begin{array}{c}\text { Isochrysin } \\
\text { galbana, } \\
\text { Selenastrum } \\
\text { capricornutum }\end{array}$ & $\begin{array}{c}\text { sewage } \\
\text { sludge }\end{array}$ & $\begin{array}{l}\text { Reactor: } 2 \text { batch reactors }(120 \mathrm{~mL} \text { each), reactor } \\
\text { feed: } 100 \% \text { sludge and } 25 \%, 50 \%, 75 \% \text { and } 100 \% \\
\text { of the sludge was replaced with microalgae } \\
\text { respectively, } \\
\text { Temperature: } 33^{\circ} \mathrm{C} ; 50^{\circ} \mathrm{C} \text {, } \\
\text { Duration: } 35 \text { days }\left(33^{\circ} \mathrm{C}\right), 20 \text { days }\left(50^{\circ} \mathrm{C}\right) \text {, } \\
\text { Conclusions: during co-digestion with the higher } \\
\text { microalgae content was the lower the biogas } \\
\text { production }\end{array}$ & 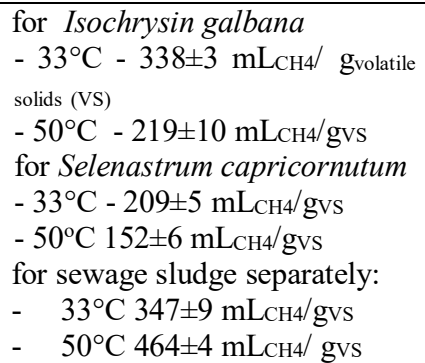 & {$[8]$} \\
\hline
\end{tabular}

\footnotetext{
$\overline{\text { * Corresponding author: mpawlita@wp.pl }}$
} 
Table 1 cont

\begin{tabular}{|c|c|c|c|c|}
\hline $\begin{array}{c}\text { macro-algae: } \\
\text { Cladophora } \\
\text { glomerata }(C G), \\
\text { Chara fragilis } \\
\text { (CF), } \\
\text { Spirogyra } \\
\text { neglecta }(S N)\end{array}$ & - & $\begin{array}{l}\text { Reactor: batch reactors with a total volume of } 5 \mathrm{~L} \\
\text { and a working volume of } 3 \mathrm{~L} \text { (in the bioreactor } \\
\text { substrate amounted to } 3 \mathrm{~L} \text { ), } \\
\text { Temperature: } 35 \pm 1{ }^{\circ} \mathrm{C} \text {, } \\
\text { Mixing: mechanical shaking } 10-15 \mathrm{~min} / \text { day, } \\
\text { Duration: } 15 \text { days, } \\
\text { Conclusions: the amount of biogas and methane, } \\
\text { indicates that the most suitable algae for the } \\
\text { production of energy are } S N \text { and } C G\end{array}$ & $\begin{array}{l}\text { for Spirogyra neglecta: } \\
\text { biogas: } 0.23 \mathrm{~m}^{3} / \mathrm{m}^{3} \text { day, } 46.5 \% \\
\mathrm{CH}_{4} \text {, } \\
\text { for Cladophora glomerata: } \\
\text { biogas: } 0.20 \mathrm{~m}^{3} /\left(\mathrm{m}^{3} \text { day }\right), 51.4 \\
\% \mathrm{CH}_{4}, \\
\text { for Chara fragilis: } \\
\text { biogas: } 0.12 \mathrm{~m}^{3} /\left(\mathrm{m}^{3} \text { day }\right), 36.9 \% \\
\mathrm{CH}_{4}\end{array}$ & [9] \\
\hline $\begin{array}{l}\text { Chlorella } \\
\text { vulgaris } \\
\text { (pure strain } \\
211 / 11 B \text { ) }\end{array}$ & - & $\begin{array}{l}\text { Reactor: double wall glass reactor (1L effective } \\
\text { volume) coupled to photobioreactor with an settling } \\
\text { facility to concentrate microalgae before feeding } \\
\text { reactor, } \\
\text { Temperature: } 35^{\circ} \mathrm{C} \text {, } \\
\text { Mixing: magnetic stirrer (continuous), } \\
\text { Duration: } 16 \text { and } 28 \text { days HRT, } \\
\text { Conclusions: carbon and nitrogen fractions of the } \\
\text { microalgae showed different responses towards } \\
\text { anaerobic degradation; fast nitrogen release is liable } \\
\text { to limit intensification capacities of the process }\end{array}$ & $\begin{array}{l}-16 \text { days }-110 \mathrm{~mL}_{\mathrm{CH}_{4}} / \mathrm{g}_{\mathrm{COD} \text { in }} \\
29 \% \mathrm{CH}_{4} \text { in gas, } \\
-28 \text { days }-180 \mathrm{~mL}_{\mathrm{CH}} / \mathrm{g}_{\mathrm{CODin}} ; \\
49 \% \mathrm{CH}_{4} \text { in gas }\end{array}$ & [10] \\
\hline $\begin{array}{l}\text { Scenedesmus sp. } \\
\text { and Chlorella sp. }\end{array}$ & $\begin{array}{l}\text { waste } \\
\text { paper }\end{array}$ & $\begin{array}{l}\text { Reactor: volume } 5.25 \mathrm{~L} \text { with gas storage tank } 7.52 \\
\mathrm{~L} \text {; working volume } 4 \mathrm{~L} \text {; semi-continuous feeding; } \\
\text { fed } 1 \text { time per day following the removal of the } \\
\text { same volume of effluent, } \\
\text { Temperature: } 35 \pm 1^{\circ} \mathrm{C} \text {, } \\
\text { Mixing: manual mixing by use of permanently } \\
\text { installed mixing rod, } \\
\text { Duration: } 10 \text { days HRT, } \\
\text { Conclusions: the optimized C/N range for the co- } \\
\text { digestion was } 20-25 / 1 \text {; increase in cellulase activity } \\
\text { helpful in the biodegradation of algal sludge }\end{array}$ & $\begin{array}{l}\text { - for algal sludge: } 573 \pm 28 \mathrm{CH}_{4} \\
\mathrm{ml} /(\mathrm{Lday}) \text {, } \\
\text { - for } 25 \% \text { waste paper }+ \text { algal } \\
\text { sludge - } 968 \pm 73 \quad \mathrm{CH}_{4} \\
\mathrm{~mL} /(\mathrm{Lday}) \text {, } \\
\text { - for } 50 \% \text { waste paper }+ \text { algal } \\
\text { sludge - } 1170 \pm 75 \mathrm{CH}_{4} \\
\mathrm{~mL} /(\mathrm{Lday}) \text {, } \\
\text { - for } 75 \% \text { waste paper }+ \text { algal } \\
\text { sludge } 317 \pm 114 \\
\mathrm{ml} /(\mathrm{Lday}), \\
\text { - for } 100 \% \text { waste paper - } \\
452 \pm 36 \mathrm{CH} 4 \mathrm{~mL} /(\text { Lday) }\end{array}$ & [11] \\
\hline $\begin{array}{l}\text { Chlorella } \\
\text { vulgaris }\end{array}$ & - & $\begin{array}{l}\text { Reactor: batch reactors } 0.120 \mathrm{~L} \text {; glass bottles } \\
\text { closed with butyl rubber seals and aluminium caps; } \\
\text { working volume } 0.070 \mathrm{~L}, 42 \% \text { head space for gas } \\
\text { production, high pressure thermal pre-treatment } \\
140^{\circ} \mathrm{C} \text { ( } 3 \text { bar) and } 160^{\circ} \mathrm{C} \text { ( } 6 \text { bar) and } 180^{\circ} \mathrm{C} \text { ( } 10 \text { bar) } \\
\text { Temperature: } 35^{\circ} \mathrm{C} \text {, } \\
\text { Mixing: orbital shaker, } \\
\text { Duration: } 29 \text { days, } \\
\text { Conclusions: high pressure thermal pretreatment } \\
\text { resulted anaerobic biodegradability of } C \text {. vulgaris; } \\
\text { highest anaerobic biodegradability }(74 \%) \text { was } \\
\text { provided by the biomass subjected to } 160^{\circ} \mathrm{C} \text {, while } \\
\text { higher temperatures did not enhance methane yield }\end{array}$ & $\begin{array}{l}\text { - average methane content in } \\
\text { the biogas }-66-68 \% \text {, } \\
\text { - raw biomass gave methane } \\
\text { yield of } 156.4 \mathrm{mLCH} / \mathrm{g}_{\text {CODin }}\end{array}$ & [12] \\
\hline Chlorella sp. & $\begin{array}{c}\text { waste } \\
\text { activated } \\
\text { sludge }\end{array}$ & $\begin{array}{l}\text { Reactor: batch reactor }(150 \mathrm{~mL}) \text {, Reactor feed: } \\
10 \% \text { of sludge by volume; alge: } 0 \%, 4 \%, 11 \% \text {, and } \\
41 \% \text {, and } 100 \% \text {, } \\
\text { Temperature: } 37^{\circ} \mathrm{C} \text {, } \\
\text { Mixing: multi-magnetic stirrers, } \\
\text { Duration: } 45 \text { days, } \\
\text { Conclusions: mesophilic anaerobic co-digestion } \\
\text { was a suitable approach to increase the biogas yield }\end{array}$ & $\begin{array}{l}\text { - the methane yield of pure } \\
\text { algae digestion } \\
\text { mLCH} / \mathrm{gVS}_{\text {fed }} \text { on } 45 \text { day }\end{array}$ & [13] \\
\hline $\begin{array}{c}\text { Chlorella } \\
\text { vulgaris }\end{array}$ & - & $\begin{array}{l}\text { Reactor: serum bottles; thermal pre-treatment } \\
120^{\circ} \mathrm{C} \text { (for } 20 \text { and } 40 \mathrm{~min} \text { ) and adding } 4 \mathrm{M} \\
\text { sulphuric acid to achieved } \mathrm{pH} 2 \text { for acid and adding } \\
4 \mathrm{M} \text { sodium hydroxide to get } \mathrm{pH} 10 \text { for the alkali } \\
\text { treatment, } \\
\text { Temperature: } 35^{\circ} \mathrm{C} \text {, } \\
\text { Mixing: shaker }(120 \mathrm{rpm}), \\
\text { Duration: } 30 \text { days, } \\
\text { Conclusions: the pretreatment improved methane } \\
\text { production, thermal treatment at } 120^{\circ} \mathrm{C} \text { for } 40 \text { min } \\
\text { led to the highest anaerobic biodegradability; this } \\
\text { pretreatment doubled methane production } \\
\text { compared to that of the raw microalgae }\end{array}$ & $\begin{array}{l}\text { - not treated } 138.9 \\
\mathrm{mLCH}_{4} / \mathrm{gCOD}_{\text {in }}\left(69.9 \% \mathrm{CH}_{4}\right) \\
\text {-thermal } 20 \min 180.3 \mathrm{~mL} \\
\mathrm{CH}_{4} / \mathrm{gCOD}_{\text {in }}\left(67.3 \% \mathrm{CH}_{4}\right) ; 40 \\
\text { min } 267.7\left(68.3 \% \mathrm{CH}_{4}\right) \\
-20 \mathrm{~min} .+ \text { acid } 221.8 \mathrm{mLCH}_{4} / \mathrm{g} \\
\mathrm{COD}_{\text {in }}\left(70.6 \% \mathrm{CH}_{4}\right) \\
-40 \text { min. }+ \text { acid } 228.8 \mathrm{mLCH}_{4} / \mathrm{g} \\
\mathrm{COD}_{\text {in }}\left(66.3 \% \mathrm{CH}_{4}\right) \\
-20 \text { min. }+ \text { alkali } 237.9 \mathrm{~mL} \mathrm{CH}_{4} / \mathrm{g} \\
\mathrm{COD}_{\text {in }}\left(68.8 \% \mathrm{CH}_{4}\right) \\
-40 \mathrm{~min} .+ \text { alkali } 240.6 \quad(70.1 \% \\
\left.\mathrm{CH}_{4}\right)\end{array}$ & [14] \\
\hline
\end{tabular}




\section{Methodology}

Chlorella vulgaris BA-0167 algae were cultivated in four glass tanks with capacity of $2 \mathrm{dm}^{3}$ each. The test stand is presented in Fig. 2.

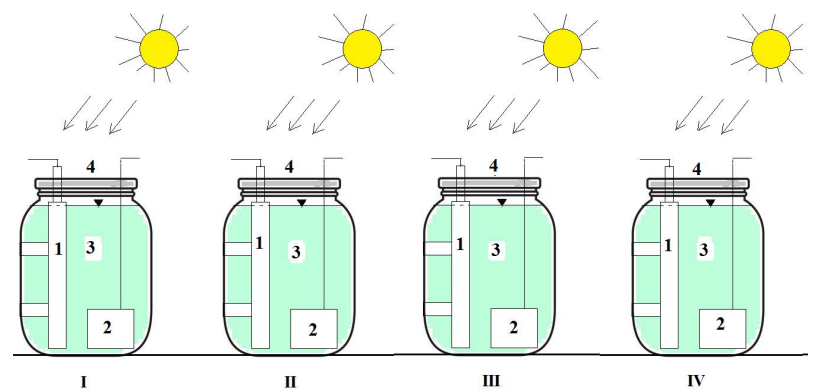

Fig. 2. Experimental stand for Chlorella vulgaris cultivation. 1-heater with a thermostat, 2 - circulation pump, 3 - tank with culture medium, 4 - semipermeable barrier for gases.

Four glass tanks were inoculated with Chlorella vulgaris BA-0167 strain (Fig. 3.) The inoculum was cultivated at the surroundings temperature of $22-24{ }^{\circ} \mathrm{C}$ on a standard $\mathrm{f} / 2$ medium, in $500 \mathrm{~mL}$ Erlenmeyer flasks. For protection against contamination, the flasks were sterilised in the autoclave at $121^{\circ} \mathrm{C}$ for 20 minutes. The strain was obtained from the CCBA (Culture Collection of Baltic Algae, Institute of Oceanography, University of Gdańsk). To initiate cultivation of algae under laboratory conditions, the same volume equal $0.2 \mathrm{dm}^{3}$ of inoculum was used, which was put in each tank and filled with demineralised water to the working volume of $2 \mathrm{dm}^{3}$.

Heaters with thermostat (1) were put in the culture tanks (Fig. 2), which allowed maintaining the same set temperature throughout algae cultivation. The literature reports various ranges of changes in the temperature for anaerobic mesophilic fermentation. According to Jankowska et al. [31], the range of temperature should be within $30^{\circ} \mathrm{C}-38^{\circ} \mathrm{C}$. On the other hand Santosh et al. [32] indicates the temperature range of $30-40^{\circ} \mathrm{C}$ and Weiland [33] $35-42^{\circ} \mathrm{C}$. In the absence of the temperature range unequivocally determined for mesophilic fermentation, the experiment was conducted at various temperatures, i.e. $33^{\circ} \mathrm{C}$ (1st tank), $35^{\circ} \mathrm{C}$ (2nd tank), $38^{\circ} \mathrm{C}$ (3rd tank) and $40^{\circ} \mathrm{C}$ (4th tank).

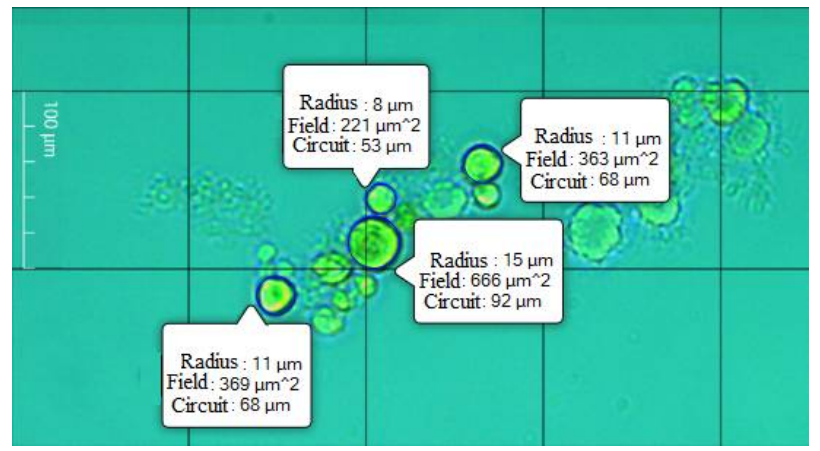

Fig. 3. Microscopic view of Chlorella vulgaris BA-0167 (typical size of single cell is $4 \mu \mathrm{m}$, in the picture visible clusters of cells after a few days of cultivation).
Algae are cultivated in natural light. Algae suspension was mixed on a stream basis in a full immersion circulation pump (2). The pump worked in 15-minutes cycles. Thanks to a time programmer unit it was possible to control the operation of the pump, which guaranteed proper circulation of the culture medium and reduced the risk of photoinhibition. Before the experiment was started, the algae culture was supplied with commercially available nutrient medium, i.e. NPK fertiliser solution with macroelements, in the amount of $1 \mathrm{~mL}$ per tank. Algae were cultivated in batch mode for 10 days, (after this time it was observed the reduction in biomass concentration).

The algae was cultivated until the algae biomass concentration decreased in all tanks, i.e. for 10 days. Every day, $\mathrm{pH}$ and temperature were taken with the Elmetron CP-401 pH-meter, which made it possible to measure both those values.

The effectiveness of algae biomass growth was determined with the Thermo Scientific Orion Aquamate $8000 \mathrm{UV}-\mathrm{V}$ is spectrophotometer. Each time, a $3500 \mu \mathrm{L}$ algae sample was collected with automatic pipette Sartorius from a culture tank and its optical density was determined. The measurement of absorbance of algae suspension at $684.0 \mathrm{~nm}$ wave length allowed monitoring of algae biomass growth. A developed analytical curve defining the change in absorbance in relation to algae concentration directly allowed reading algae concentration in $\mathrm{mg} / \mathrm{L}$ from spectrophotometer. An algae sample was always observed microscopically to monitor the condition of a culture (e.g. quantity and size of algae cells) with the Inverted microscope Motic AE 2000-T (under 40x magnification) equipped with digital camera Moticam 5+ and image analysis software (Fig. 3).

\section{Results and discussion}

A significant effect on the efficiency of biogas production and algae cultivation is mixing, temperature and $\mathrm{pH}$. The applied mixing allowed, for instance, transport of $\mathrm{CO}_{2}$, removal of $\mathrm{O}_{2}$ generated in photosynthesis from a tank, favourable access to light and uniform distribution of nutrients as well as heat throughout the reactor. The $\mathrm{pH}$ values measured in the culture tanks were changing from 6.88 to 8.07 . The $\mathrm{pH}$ range in own studies corresponded to the conditions of growth of most algae on culture media, i.e. $\mathrm{pH}$ of 7-9 $[17,21]$. Moreover, that range corresponded with the optimal conditions for biogas production, i.e. $\mathrm{pH} 6.5-$ 8.0 [34]. The oscillation of temperature in algae culture did not exceed $\pm 1{ }^{\circ} \mathrm{C}$. Fig. 4 shows a change in the biomass concentration over time.

The highest increase in biomass concentration, almost twofold, was achieved in a culture tank at $33^{\circ} \mathrm{C}$, where the biomass concentration increase from 0.176 to $0.331 \mathrm{mg} / \mathrm{dm}^{3}$, and after day 8 of cultivation, there was a slight decrease in the algae biomass concentration up to $0.326 \mathrm{mg} / \mathrm{dm}^{3}$. Experimental data indicate that after a relatively short period, the rate of algae biomass gain at $33^{\circ} \mathrm{C}$ stabilised. At $35^{\circ} \mathrm{C}$, there was a minimum increase

\footnotetext{
*Corresponding author: mpawlita@wp.pl
} 
in the algae biomass concentration only to day 3 of the cultivation, i.e. from $0.176 \mathrm{mg} / \mathrm{dm}^{3}$ to $0.237 \mathrm{mg} / \mathrm{dm}^{3}$, and subsequently a concentration decreased to 0.172 $\mathrm{mg} / \mathrm{dm}^{3}$. In turn, in the case of algae cultivation at $38^{\circ} \mathrm{C}$ and $40^{\circ} \mathrm{C}$, the algae concentration was constantly decreasing from $0.176 \mathrm{mg} / \mathrm{dm}^{3}$ to $0.072 \mathrm{mg} / \mathrm{dm}^{3}$ and $0.054 \mathrm{mg} / \mathrm{dm}^{3}$, respectively.

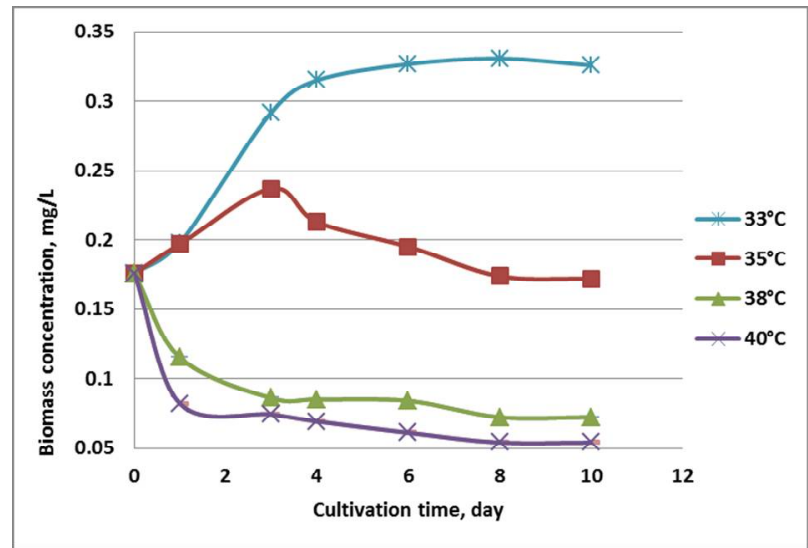

Fig. 4. Changes in Chlorella vulgaris BA-0167 biomass concentration over time.

The algae biomass concentration decrease observed in the experiments at $35^{\circ} \mathrm{C}$ is also confirmed by studies conducted by Fernandez et al. [28], who noted similar behaviour of microalgae Phaeodactylum tricornutum in a spiral reactor. The authors of [28] indicated for instance that temperature and dissolved oxygen are factors limiting algae growth. Dziosa and Makowska [21], who investigated growth of biomass of fresh-water microalgae cultivated in laboratory bioreactors, also did not note any increase in biomass productivity upon temperature increase up to $30^{\circ} \mathrm{C}$, only an increase in cultivation costs. In turn, Converti et al. [35] state that the rate of growth of Chlorella vulgaris at $35^{\circ} \mathrm{C}$ decrease by $17 \%$ compared to the productivity observed at $30^{\circ} \mathrm{C}$. At $38^{\circ} \mathrm{C}$, microalgae stopped growing and cells started to decay. As the temperature increased to $30^{\circ} \mathrm{C}$, the rate of cell growth increased; on the other hand, as the temperature increased from 30 to $35-{ }^{\circ} \mathrm{C}[36,37]$, the rate went down.

Present studies showed decrease in algae concentration (Fig. 4), which most probably results from the nutrient medium losing its nutrients (batch culture, no medium feeding) and the application of unfavourable temperature conditions. Ma et al. [1] stated that the optimal temperature conditions for Chlorella vulgaris are $25^{\circ}-28^{\circ} \mathrm{C}$; on the other hand, Leyva et al. [26] state that it is $27^{\circ} \mathrm{C}$. These temperatures are lower than the temperature applied in algae cultivation system examined in present study. During cultivation, algae grouped into clusters, or floccules (Fig. 5). On walls of photobioreactors, biofilm was formed, which indicates that the algae needed a higher access to light and/or the applied mixing method was insufficient. The algae culture was exposed to sunlight of variable intensity. Photoinhibition was observed (visible in bleaching cells in Fig. 6), which contributed to algae death (Fig. 7).

An analysis of results obtained from studies on change in algae concentration over time at various cultivation temperatures (Fig. 4) allows stating that algae cultivation at the set temperatures of $33{ }^{\circ} \mathrm{C}, 35^{\circ} \mathrm{C}, 38^{\circ} \mathrm{C}$ and $40^{\circ} \mathrm{C}$ does not allow high algae biomass gains.

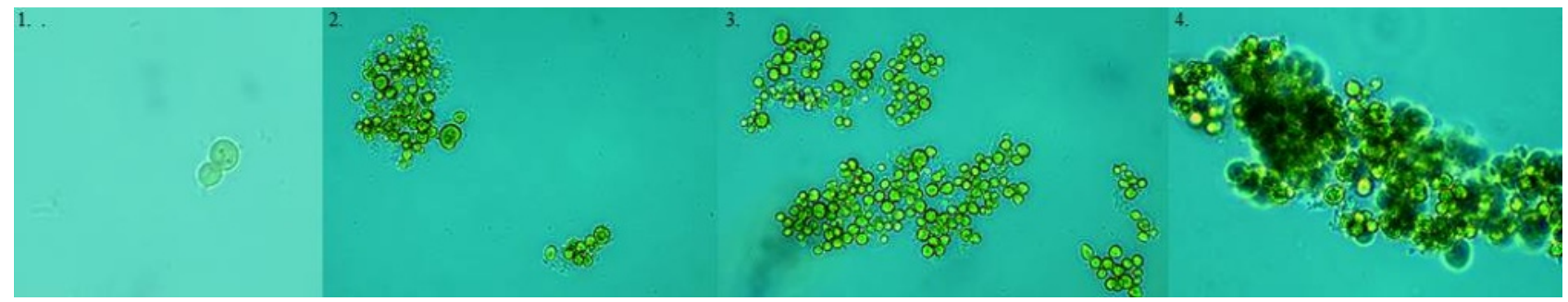

Fig. 5. Formation of algae clusters - floccules during cultivation time (1-4).

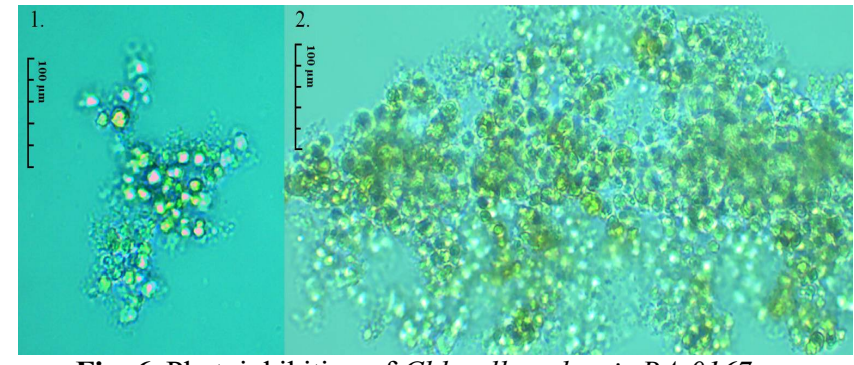

Fig. 6. Photoinhibition of Chlorella vulgaris BA-0167.

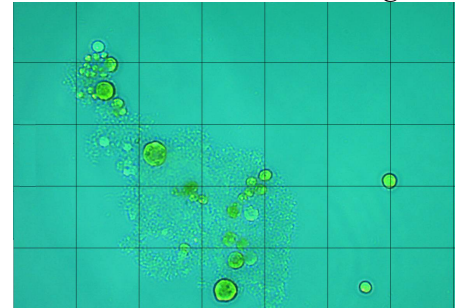

Fig. 7. Reduction in the number of algae cells in the medium.
Experimental test of culture of algae is presented in Fig. 8.

The authors of papers [8-14,31] evaluated the usefulness of various algae species for biogas production by way of fermentation or co-fermentation using various substrates and determining diverse conditions of the process. Montingelli et al. [38] presented the process of biogas production at various temperatures, using such algae species as Ulva lactuca $\left(50^{\circ} \mathrm{C}, 53^{\circ} \mathrm{C}\right)$, Laminaria hyperborea $\left(35^{\circ} \mathrm{C}\right)$, Laminaria sp. $\left(50^{\circ} \mathrm{C}\right)$, Ascophyllum nodosum $\left(35^{\circ} \mathrm{C}\right)$, Chlorella vulgaris $\left(35^{\circ} \mathrm{C}\right)$, Chlorella $s p$. $\left(25^{\circ} \mathrm{C}\right)$, etc. For example the methane potentials of cyanobacteria and Chlorella have been investigated in eight different lab scale reactors $\left(25^{\circ} \mathrm{C}\right.$, three-day HRT). It was stated that the highest methane production rates of Chlorella were $100 \pm 25 \mathrm{~mL} /(\mathrm{L} \cdot \mathrm{d})$, at loading rate of $7 \mathrm{~g}$ VS $[38,39]$. The results of experimental research indicate [8-14] that it is possible to use various algae species as 
substrates or co-substrates in the process of biogas production and depending on the conditions under which the process is conducted and the temperature optimum characteristic for individual algae species, one should expect diverse amounts of produced biogas.

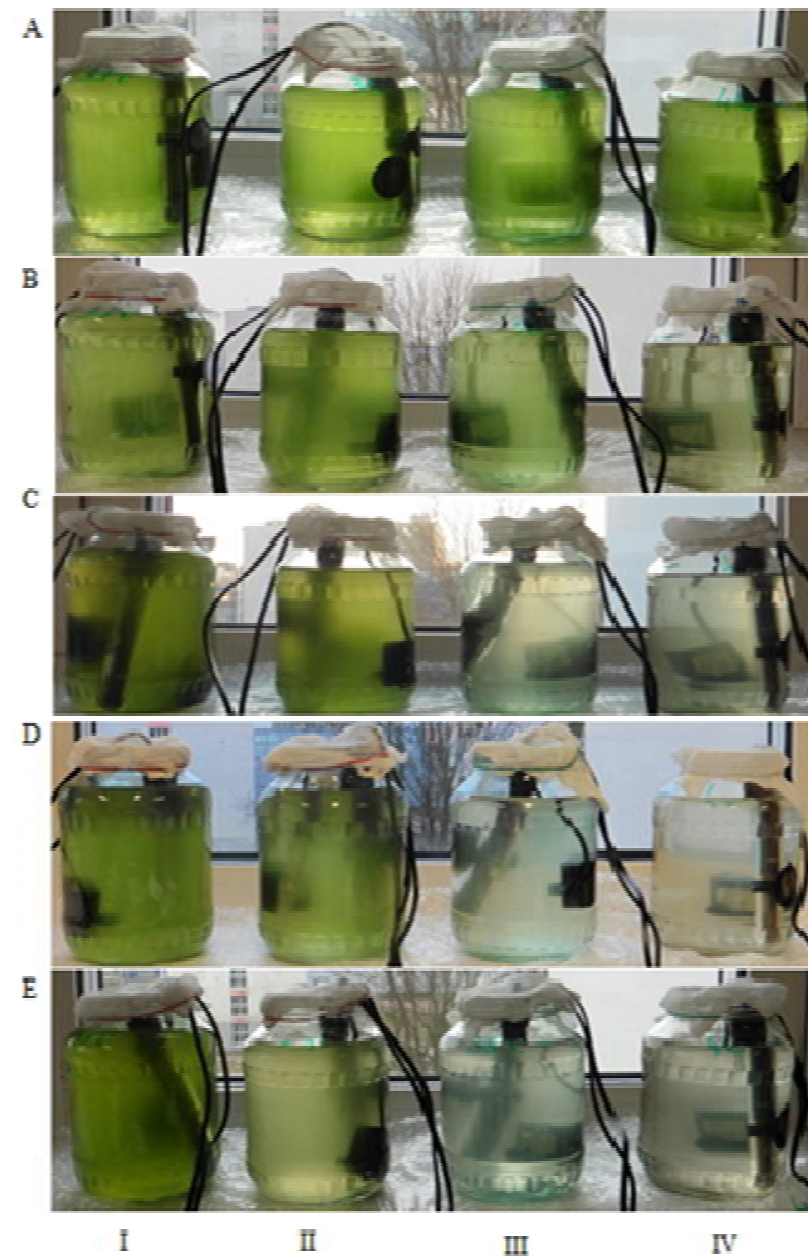

Fig. 8. Cultivation of algae Chlorella vulgaris BA-0167 A - start of cultivation (day 0), B - $1^{\text {st }}$ day of cultivation, C- $3^{\text {rd }}$ day of cultivation, D $-8^{\text {th }}$ day of cultivation, E - end of experiment $\left(10^{\text {th }}\right.$ day of cultivation).

\section{Conclusions}

Mostly due to high rate of growth (photosynthesis), ability to accumulate in cells of lipids and other organic compounds as a result of conversion of $\mathrm{CO}_{2}$ into biomass and low nutritional requirements (water, light, $\mathrm{CO}_{2}, \mathrm{~N}$, $\mathrm{P}$, etc.), algae are treated as a potential substrate or co-substrate used in the production of biofuels, including biogas. Depending on the species of algae being fermented, the amount of produced biogas can differ considerably. Among others, very important factor influencing the effectiveness of algae biomass productivity under conditions favourable for anaerobic fermentation is the temperature of the process. In present studies under conditions of anaerobic mesophilic fermentation conducted at $35^{\circ} \mathrm{C}, 38^{\circ} \mathrm{C}$ and $40^{\circ} \mathrm{C}$, the productivity of the biomass of algae Chlorella vulgaris $B A-0167$ was decreasing virtually from the first day of cultivation (at $38^{\circ} \mathrm{C}$ and $40^{\circ} \mathrm{C}$, respectively), which indicates decay of algae cells under those conditions. It was also found that only the temperature of $33^{\circ} \mathrm{C}$ allows a nearly twofold increase in biomass concentration.

The research confirms the necessity to modify the conditions of cultivation, because of limited algae biomass growth. The changes concern such aspects as increase in the frequency of nutrient medium supply, use of artificial light source and constant magnetic mixing. Expanding the experimental data base in this manner will allow to determine whether the improvement in culture conditions influences an effective growth of algae under the assumed cultivation conditions in terms of temperatures favourable for anaerobic mesophilic fermentation, i.e. $33^{\circ} \mathrm{C}-40^{\circ} \mathrm{C}$.

\section{References}

1. S. Ma, B. Han, V.A.R. Huss, X. Hu, X. Sun, J. Zhang, Hydrobiologia 760, 1 (2015)

2. C. Posten, G. Shaub, J. Biotechnol. 142 (2009)

3. M. Płaczek, A. Patyna, S. Witczak, E3S Web of Conferences 19 (2017)

4. M. Pawlita-Posmyk, M. Wzorek, Chemik 70, 10 (2016)

5. M. Dębowski, M. Zieliński, A. Grala, M. Dudek, Renew. Sust. Energ. Rev. 27 (2013)

6. S.H. Shah, I.A. Raja, M. Rizwan, N. Rashid, Q. Mahmood, F.A. Shah, A. Pervez, Renew. Sust. Energ. Rev. 81 (2018)

7. M. Pawlita-Posmyk, M. Wzorek, E3S Web of Conferences 19 (2017)

8. M. P. Caporgno, R. Trobajo, N. Caiola, C. Ibáñez, A. Fabregat, C. Bengoa, Renew. Energ. 75 (2015)

9. P. Baltrènas, A. Misevičius, J. Environ. Health Sci. Eng. 13, 18 (2015)

10. M. Ras, L. Lardon, S. Bruno, N. Bernet, J.P. Steyer, Bioresour. Technol. 102, 1 (2011)

11. H.W. Yen, D.E. Brune, Bioresour. Technol. 98 (2007)

12. L. Mendez, A. Mahdy, M. Demuez, M. Ballesteros, C. González-Fernández, Fuel 117 (2014)

13. M. Wang, A.K. Sahu, B. Rusten, C. Park, Bioresour. Technol. 142 (2013)

14. L. Mendez, A. Mahdy, R.A. Timmers, M. Ballesteros, Bioresour. Technol. 149 (2013)

15. D. Kępska, Ł. Olejnik, Chemik 68, 11 (2014)

16. Q. Béchet, A. Shilton, B. Guieysse, Biotechnol. Adv. 31 (2013)

17. M. Frąc, M. S. Jezierska-Tys, J. Tys, Acta Agrophysica 13, 3 (2009)

18. Y. Chisti, Biotechnol. Adv. 25 (2007)

19. M. Frąc, S. Jezierska-Tys, J. Tys, Afr. J. Biotechnol. 9, 54 (2010)

20. W. Kozieł, T. Włodarczyk, Acta Agroph. 17, 1 (2011)

21. K. Dziosa, M. Makowska, Inż. Ap. Chem. 54, 4 (2015) 
22. A. Kumar, S. Ergas, X. Yuan, A. Sahu, Q. Zhang, J. Dewulf, F. X. Malcata, Trends in Biotechnology 28 (2010)

23. S.P. Shukla, J. Kviderová, J. Třiska, J. Elster, Front Microbiol. 4 (2013)

24. S. Cao, X. Zhou, W. Jin, F. Wang, R. Tu, S. Han, H. Chen, C. Chen, G.J. Xie, F. Ma, Bioresour. Technol. 244, 2 (2017)

25. Z. Ouyang, X. Wen, Y. Geng, H. Mei, H. Hu, G. Zhang, Y. Li, J. Wuhan Bot. Res. 28, 1 (2010)

26. L.A. Leyva, Y. Bashan, A. Mendoza, L.E. deBashan, Naturwissenschaften 101, 10 (2014)

27. H.P. Kusumaningrum, M. Zainuri, Int. J. Mar. Aquat. Res. Conserv. Co-Exist. 1,1 (2014)

28. F.G. Acién Fernández, D.O. Hall, E. Cañizares Guerrero, K.K. Rao, E. Molina Grima, J. Biotechnol. 103 (2003)

29. Y. Chisti, Biotechnol. Adv. 25 (2007)

30. R.A. Voloshin, M.V. Rodionova, S.K. Zharmukhamedov, T.N. Veziroglu, S.I. Allakherdiev, Int. J. Hydrogen Energ. 41, 39 (2016)

31. E. Jankowska, A.K. Sahu, P. Oleskowicz-Popiel, Renew. Sust. Energ. Rev. 75 (2017)

32. Y. Santosh, T.R. Sreekrishnan, S. Kohli, V. Rana, Bioresour. Technol. 95, 1 (2004).

33. P. Weiland, Appl. Microbiol. Biotechnol. 85, 4 (2010)

34. S. O. Dahunsi, S. Oranusi, V.E. Efeovbokhan, J. Clean. Prod. 156 (2017)

35. A. Converti, A. A. Casazza, E. Y. Ortiz, P. Perego, M. D. Borghi, Chem. Eng. Process. 48 (2009)

36. K.O. Cassidy, Theses and Dissertations-Biosystems and Agricultural Engineering, 2011

37. S. Daliry, A. Hallajisani, J.M. Roshandeh, H. Nouri, A. Golzary, Global J. Environ. Sci. Manage 3, 2 (2017)

38. M.E. Montingelli, S. Tedesco, A. G. Olabi, Renew. Sust. Energ. Rev. 43 (2015)

39. A. O. Jegede, Int. J. Agric. \& Biol. Eng. 5, 3 (2012) 